\title{
Effect of thermal boundary conditions on the response of thermally-activated floating piles in a cohesive material
}

\author{
Peter Bourne-Webb ${ }^{1, *}$, Martina Zito $^{2}$, Teresa Maria Bodas Freitas ${ }^{1}$, and Donatella Sterpi ${ }^{2}$ \\ ${ }^{1}$ CERIS, Instituto Superior Técnico, Universidade de Lisboa, Lisboa, Portugal \\ ${ }^{2}$ Politecnico di Milano, Milano, Italia
}

\begin{abstract}
The application of thermally-activated foundations has received significant attention in the last decade with a number of large- and small-scale tests having been undertaken. Alongside these physical studies, a number of investigations utilising numerical analysis have been undertaken. The majority of analyses are transient with durations from a few hours up to 10 years. A broad range of thermal boundary and initial conditions have been applied in these analyses, and only a limited number of studies have explicitly considered the surface boundary imposed by an overlying structure, let alone considered what effect variations in the operational temperatures of the structure might have on the foundations. The work presented in this paper had the objective of systematically examining these assumptions and the effect they have on the predicted response of a thermally-activated pile foundation, and if important, which is the most appropriate set of conditions to use.
\end{abstract}

\section{Introduction}

The application of thermally-activated foundations has received significant attention in the last decade with a number of large- and small-scale tests having been undertaken. Alongside these physical studies, a number of investigations utilising numerical analysis have been undertaken, some of which, [1] to [20], are tabulated in Table 1. The majority of analyses are transient with durations from a few hours [6] where small-scale tests have been analysed, up to 10 years [18].

Examining the side and bottom boundary conditions applied, adiabatic (no flow) or constant temperature conditions have been used more-or-less equally. Generally, the centreline condition is adiabatic, except in some pile group studies where constant temperature conditions were applied to all boundaries.

Surface temperature boundary conditions are in most cases defined using either a constant temperature [3, 9], often the same as the initial temperature $[1,4$ to 8,11 , $13,15,17,20]$, or in a few cases an imposed temperature harmonic representing the change in average air temperature across the year [16, 18]. Only, a limited number of studies have explicitly considered the surface boundary imposed by an overlying structure [2, 3], let alone considered what effect variations in the operational temperatures of the structure might have on the foundations [9, 21].

The pile thermal load has in most cases been applied across the elements forming the pile, either as a stepped or ramped temperature change or a prescribed heat flux $[2,3,7]$. In some analyses, the thermal load has been applied along lines within the pile body (ring in 2D analysis), again either as temperature change $[6,13,16$, 20] or a heat flux $[15,19]$.

This illustrates the broad range of assumptions that can be made in initialising the analysis of thermallyactivated foundations. Using steady-state analyses, Bodas Freitas et al. [1] showed that the choice of either a constant temperature or adiabatic surface condition could have a profound effect on the predicted temperature field and hence, the response of the pile during subsequent thermal loading, Fig. 1. This was further expanded upon by Bourne-Webb et al. [9] and [21] under similar conditions, however the effect in a transient thermal loading condition was not explored.

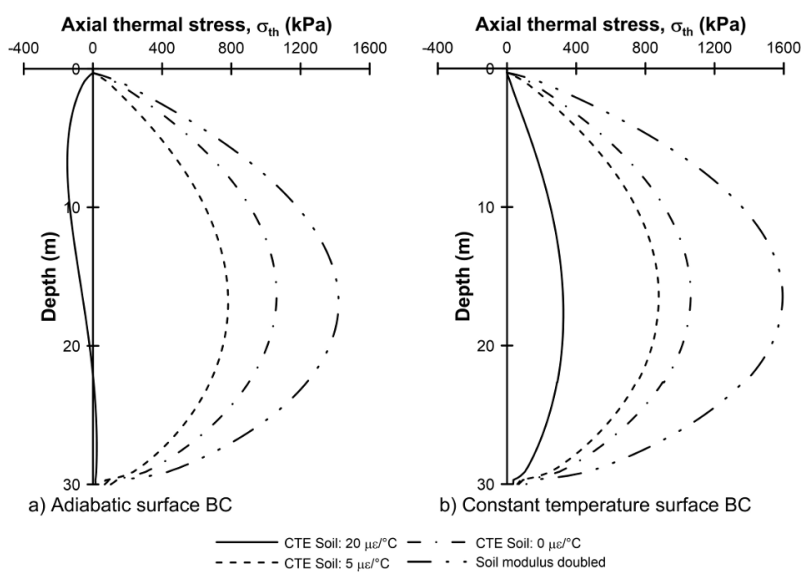

Fig. 1. Effect of surface boundary assumption on the response of thermally-activated piles, [01] Bodas Freitas et al. 2013. 
Table 1. Thermal boundary conditions reported for numerical analyses of thermally-activated piles and pile groups.

\begin{tabular}{|c|c|c|c|c|c|c|c|}
\hline Source & $\begin{array}{l}\text { Analysis } \\
\text { (Duration) }\end{array}$ & $\mathrm{T}_{0},{ }^{\circ} \mathrm{C}$ & $\begin{array}{c}\text { Surface } \\
\left(\mathrm{T}_{\mathrm{M}} \& \Delta \mathrm{T}\right)\end{array}$ & $\begin{array}{c}\text { Centreline/ } \\
\text { Internal (3D) }\end{array}$ & Side & Bottom & $\begin{array}{l}\text { Pile heating } \\
\left(\mathrm{T}_{\mathrm{M}} \& \Delta \mathrm{T}\right)\end{array}$ \\
\hline$[1]$ & $\begin{array}{l}\text { Steady } \\
\text { State }\end{array}$ & 15 & $\begin{array}{l}\mathrm{T}=\mathrm{T}_{0} \text { or } \\
\text { Adiabatic }\end{array}$ & Adiabatic & Const. $\mathrm{T}=\mathrm{T}_{0}$ & Const. $\mathrm{T}=\mathrm{T}_{0}$ & Body; Step $\left( \pm 30^{\circ} \mathrm{C}\right)$ \\
\hline$[2]$ & $\begin{array}{l}\text { Transient } \\
(7 \mathrm{yr})\end{array}$ & 11 & $\begin{array}{c}\text { Adiabatic; } \\
\text { Slab: } \mathrm{T}=15^{\circ} \mathrm{C}\end{array}$ & Adiabatic & Adiabatic & Adiabatic & Body; Step $\pm 150 \mathrm{~W} / \mathrm{m}$ \\
\hline$[3]$ & $\begin{array}{l}\text { Transient } \\
(7 \mathrm{yr})\end{array}$ & 11 & $\begin{array}{l}\text { Const. } \mathrm{T} \neq \mathrm{T}_{0} \\
\text { Slab: } \mathrm{T}=15^{\circ} \mathrm{C}\end{array}$ & Adiabatic & Const. $\mathrm{T} \neq \mathrm{T}_{0}$ & Const. $\mathrm{T} \neq \mathrm{T}_{0}$ & $\begin{array}{c}\text { Body; Ramp } \pm 90 \mathrm{~W} / \mathrm{m} \\
\text { to }+245 /-225 \mathrm{~W} / \mathrm{m}\end{array}$ \\
\hline [4] & $\begin{array}{l}\text { Transient } \\
(28 \mathrm{~d})\end{array}$ & 15 & Const. $\mathrm{T}=\mathrm{T}_{0}$ & Adiabatic & Adiabatic & Adiabatic & $\begin{array}{l}\text { Body; Ramp }\left(+21^{\circ} \mathrm{C}\right) \\
\text { for } 12 \mathrm{~d} \text {, cool for } 16 \mathrm{~d}\end{array}$ \\
\hline$[5]$ & $\begin{array}{l}\text { Transient } \\
(30 \mathrm{yr})\end{array}$ & 20 & Const. $\mathrm{T}=\mathrm{T}_{0}$ & Adiabatic & Const. $\mathrm{T}=\mathrm{T}_{0}$ & Const. $\mathrm{T}=\mathrm{T}_{0}$ & $\begin{array}{c}\text { Body; Step } \\
\left(+20^{\circ} \mathrm{C} /-15 \mathrm{C}^{\circ} \mathrm{C}\right)\end{array}$ \\
\hline [6] & $\begin{array}{l}\text { Transient } \\
(3 \mathrm{hr})\end{array}$ & 20 & Const. $\mathrm{T}=\mathrm{T}_{0}$ & Adiabatic & Adiabatic & Adiabatic & Ring; Ramp $\left(+19^{\circ} \mathrm{C}\right)$ \\
\hline [7] & $\begin{array}{c}\text { Transient } \\
(10 \mathrm{yr})\end{array}$ & 11 & Const. $\mathrm{T}=\mathrm{T}_{0}$ & Const. $\mathrm{T}=\mathrm{T}_{0}$ & Const. $\mathrm{T} \neq \mathrm{T}_{0}$ & Const. $\mathrm{T}=\mathrm{T}_{0}$ & $\begin{array}{l}\text { Body; Ramp to } \\
\pm 115 \mathrm{~W} / \mathrm{m}\end{array}$ \\
\hline$[8]$ & $\begin{array}{l}\text { Transient } \\
(7 \mathrm{mths})\end{array}$ & 22 & Const. $\mathrm{T}=\mathrm{T}_{0}$ & Const. $\mathrm{T}=\mathrm{T}_{0}$ & Const. $\mathrm{T}=\mathrm{T}_{0}$ & Const. $\mathrm{T}=\mathrm{T}_{0}$ & $\begin{array}{l}\text { Body; Ramp } \\
\left(+15 /+30^{\circ} \mathrm{C}\right)\end{array}$ \\
\hline [9] & $\begin{array}{l}\text { Steady } \\
\text { State }\end{array}$ & 15 & $\begin{array}{l}\text { Const. } \mathrm{T} \neq \mathrm{T}_{0} \\
=12,18,24^{\circ} \mathrm{C}\end{array}$ & Adiabatic & Const. $\mathrm{T}=\mathrm{T}_{0}$ & Const. $\mathrm{T}=\mathrm{T}_{0}$ & Body; Step $\left( \pm 30^{\circ} \mathrm{C}\right)$ \\
\hline$[10]$ & $\begin{array}{l}\text { Transient } \\
(146 \mathrm{~d})\end{array}$ & 11 & Not stated & Not stated & Not stated & Not stated & $\begin{array}{c}\text { Body; Ramp 2x } \\
\text { (+19/500 hrs, } \\
-19 / 1300 \mathrm{hrs}) \\
\end{array}$ \\
\hline [11] & $\begin{array}{l}\text { Transient } \\
(10-31 \mathrm{~d})\end{array}$ & 18 & Const. $\mathrm{T}=\mathrm{T}_{0}$ & Const. $\mathrm{T}=\mathrm{T}_{0}$ & Const. $\mathrm{T}=\mathrm{T}_{0}$ & Const. $\mathrm{T}=\mathrm{T}_{0}$ & $\begin{array}{c}\text { Body; Step } \\
\left(-18^{\circ} \mathrm{C} ;+12^{\circ} \mathrm{C}\right)\end{array}$ \\
\hline [12] & $\begin{array}{l}\text { Transient } \\
\text { (6 mths) }\end{array}$ & 15 & Adiabatic & Const. $\mathrm{T}=\mathrm{T}_{0}$ & Const. $\mathrm{T}=\mathrm{T}_{0}$ & Const. $\mathrm{T}=\mathrm{T}_{0}$ & $\begin{array}{c}\text { Body; Step } \\
\left(\varepsilon_{\mathrm{th}} \equiv \pm 10^{\circ} \mathrm{C}\right)\end{array}$ \\
\hline [13] & $\begin{array}{l}\text { Transient } \\
(1 \mathrm{yr})\end{array}$ & 19.5 & Const. $\mathrm{T}=\mathrm{T}_{0}$ & Adiabatic & Const. $\mathrm{T}=\mathrm{T}_{0}$ & Const. $\mathrm{T}=\mathrm{T}_{0}$ & $\begin{array}{c}4 \text { no. lines; Ramp } \\
0.5^{\circ} \mathrm{C} / \text { day with } 120 \\
\text { days H\&C }\end{array}$ \\
\hline$[14]$ & $\begin{array}{l}\text { Transient } \\
(2 \mathrm{yr})\end{array}$ & 20 & Adiabatic & Adiabatic & Adiabatic & Adiabatic & $\begin{array}{l}\text { Body; Harm. } \\
\left(20 \pm 20^{\circ} \mathrm{C}\right)\end{array}$ \\
\hline$[15]$ & $\begin{array}{l}\text { Transient } \\
(1 \mathrm{yr})\end{array}$ & 10 & Const. $\mathrm{T}=\mathrm{T}_{0}$ & Adiabatic & Adiabatic & Adiabatic & $\begin{array}{c}4 \text { no. lines; flux: } \\
\text { Harm. }(0-20 \mathrm{~W} / \mathrm{m}) \\
\text { Step }( \pm 50 \mathrm{~W} / \mathrm{m})\end{array}$ \\
\hline [16] & $\begin{array}{l}\text { Transient } \\
(4 \mathrm{yr})\end{array}$ & $\approx 17^{\mathrm{a}}$ & $\begin{array}{l}\text { Harmonic } \\
\left(17 \pm 6^{\circ} C\right)^{\mathrm{b}}\end{array}$ & Adiabatic & Adiabatic & Adiabatic & $\begin{array}{l}\text { Ring at }(\mathrm{R}-0.075 \mathrm{~m}) \\
\text { Harm. }\left(22 \pm 9^{\circ} \mathrm{C}\right)\end{array}$ \\
\hline [17] & $\begin{array}{l}\text { Transient } \\
(6 \mathrm{mth})\end{array}$ & 15 & Adiabatic & Adiabatic & Const. $\mathrm{T}=\mathrm{T}_{0}$ & Const. $\mathrm{T}=\mathrm{T}_{0}$ & $\begin{array}{l}\text { Body; Step } \\
\left(\mathrm{T}_{0} \pm 15^{\circ} \mathrm{C}\right)\end{array}$ \\
\hline$[18]$ & $\begin{array}{l}\text { Transient } \\
(10 \mathrm{yr})\end{array}$ & 14 & $\begin{array}{l}\text { Harmonic } \\
\left(14 \pm 12^{\circ} \mathrm{C}\right)^{3}\end{array}$ & Adiabatic & Adiabatic & $\begin{array}{c}\text { Flux } \\
\left(0.05 \mathrm{~W} / \mathrm{m}^{2}\right)\end{array}$ & $\begin{array}{c}\text { Body; Step or } \\
\text { Harmonic }\left(14 \pm 12^{\circ} \mathrm{C}\right)\end{array}$ \\
\hline [19] & $\begin{array}{l}\text { Transient } \\
(270 \mathrm{~d})\end{array}$ & 13.4 & Adiabatic & Adiabatic & Adiabatic & Adiabatic & $\begin{array}{l}\text { Ring at interface; Flux } \\
\text { (c. } 47 \mathrm{~W} / \mathrm{m})\end{array}$ \\
\hline$[20]$ & $\begin{array}{l}\text { Transient } \\
(400 \mathrm{~d})\end{array}$ & 16.9 & Const. $\mathrm{T}=\mathrm{T}_{0}$ & Adiabatic & Adiabatic & Adiabatic & $\begin{array}{c}\text { Ring at R/2; Intmt. } \\
\text { Step }\left(-6.9^{\circ} \mathrm{C} ;+11.1^{\circ} \mathrm{C}\right)\end{array}$ \\
\hline
\end{tabular}

Notes: a. But from harmonic solution for temperature variation with depth; b. Also applied daily harmonic with $\Delta \mathrm{T}$ of $7.5^{\circ} \mathrm{C} ; \mathrm{c}$. Also applied daily harmonic with $\Delta \mathrm{T}$ of $3^{\circ} \mathrm{C}$ and hourly harmonic with $\Delta \mathrm{T}$ of $2^{\circ} \mathrm{C}$; Trans. $=$ transient; Body $>>$ changes applied across all elements in pile; Ring $>>$ changes applied along line within body of pile in $2 \mathrm{D}$ axisymmetric analysis; Const. = constant; Intmt. = intermittent; Harm. / Harmonic = time-varying (e.g. sine function); Step = instantaneous change; Ramp = gradual change;

The question is then; what effect does the choice of initial and boundary conditions have on the predicted response of the thermally-activated foundation and, if it is important, which is the most appropriate to use?
First, it is important to examine in a systematic manner the potential thermal history for a given site:

- Greenfield sites are those untouched by development and therefore the temperature field in the ground will be 
a direct reflection of the local climate and ground cover (grassland, forest).

- Brownfield / Urban sites are those that have been previously developed or are impacted either directly or indirectly by adjacent development. The ambient ground temperature may also be impacted by heat island effects, heat loss to the ground from previous development, adjacent thermal sources, in addition to the effects referred to above. For example, Bourne-Webb et al. [22] found that the ground temperature prior to the test at Lambeth College had stabilised at around $18^{\circ} \mathrm{C}$ when the average annual air temperature suggests a value around $12^{\circ} \mathrm{C}$ should be expected. This was attributed to the presence of the nearby underground railway tunnels but could also be due to the residual heat lost from the structure previously on the site.

- Construction phase activities will lead to the gradual modification of the site conditions which will depend on the type of structure being developed. This period may entail months or possibly years of activity. Effects of interest may include the isolation of the ground enveloping the foundation elements by the building structure and transient heat sources from, e.g. hydration of concrete used in the construction of the foundations and other elements.

- Operational phase effects will involve the occupation of the development, and commissioning of climate control systems and the thermally-activated foundations. In this period and depending on the internal heating and cooling requirements, and type of construction, a new thermal condition will develop on the surface overlying the foundations. Also, the foundations will be imposing thermal loads to the ground, depending on the operational needs of the climate control system.

It is clear that there are many possible initial and subsequent thermal conditions that may be pertinent to the analysis of a thermally-activated structure. This study will compare the results from a set of analyses based on a pre-conditioned Greenfield situation to those from a subset of the conditions applied in other studies, summarised in Table 1.

\section{Basis for analyses}

The 2D axisymmetric geometry selected for this assessment includes an isolated $1 \mathrm{~m}$ diameter, $30 \mathrm{~m}$ long pile embedded in a domain that extends $30 \mathrm{~m}$ radially from the pile centreline and is $90 \mathrm{~m}$ deep. A $1.6 \mathrm{~m}$ diam. by $1 \mathrm{~m}$ deep pile cap was placed at the head of the pile. The bottom boundary is fixed in the vertical and horizontal directions while the side boundary is only fixed in the horizontal direction. The analyses were undertaken using the finite element program ABAQUS.

The pile, the ground in which the pile is embedded and the pile-soil interface were modelled in the same manner as [1] \& [9] with the exception that the Young's modulus for the soil was assumed to increase from 25 $\mathrm{MPa}$ at the surface, to $175 \mathrm{MPa}$ at the bottom boundary, rather than being constant. No particular assumption was made regarding the moisture condition of the soil. The soil and pile thermal and mechanical properties are presented in Table 2.

Table 2. Pile and soil properties.

\begin{tabular}{|c|c|c|c|}
\hline Parameter & Unit & Pile & Soil \\
\hline Density, $\rho$ & $\mathrm{kg} / \mathrm{m}^{3}$ & 2450 & 1600 \\
\hline Young's modulus, E & $\mathrm{MPa}$ & 30000 & Varies \\
\hline Poisson's ratio, $v$ & - & 0.3 & 0.3 \\
\hline Shear strength, c & $\mathrm{kPa}$ & $\mathrm{n} / \mathrm{a}$ & 75 \\
\hline Pile-soil adhesion, a & $\mathrm{kPa}$ & $\mathrm{n} / \mathrm{a}$ & 75 \\
\hline $\begin{array}{c}\text { Thermal conductivity, } \mathrm{k} \\
\text { Specific heat, c }\end{array}$ & $\mathrm{W} / \mathrm{m} . \mathrm{K}$ & 2 & 1 \\
\hline $\begin{array}{c}\text { Linear coefficient of thermal } \\
\text { expansion, } \alpha\end{array}$ & $\mu \varepsilon / \mathrm{K} . \mathrm{K}$ & 940 & 1220 \\
\hline
\end{tabular}

Two initial temperature conditions were considered: 1) The initial temperature, $T_{0}$ is uniform across the problem domain with a value of $14^{\circ} \mathrm{C}$ which approximates the annual average air temperature of Milan, Italy. This was applied in the analyses identified as Comb. 1 to 4 , Table 3.

(https://www.timeanddate.com/weather/italy/milan/clima te);

2) A Greenfield condition arrived at by applying an harmonic temperature function at the ground surface, Equation (1) and Fig. 2, over a period of 10 years, after which the temperature field had "stabilised" in a dynamic thermal equilibrium with the boundary condition [23], Fig. 3. This was applied in the "Greenfield" analysis, Table 3.

$$
\mathrm{T}=\mathrm{T}_{\mathrm{avg}}+\Delta \mathrm{T} \cdot \sin \left[(2 \pi / \mathrm{P}) \mathrm{t}-\varphi_{\mathrm{t}}\right]
$$

where $\mathrm{T}_{\mathrm{avg}}=\mathrm{T}_{0}=14^{\circ} \mathrm{C}$ is the average annual air temperature; $\Delta \mathrm{T}=11^{\circ} \mathrm{C}$ is the temperature amplitude; $\mathrm{P}$ $=1$ year is the period of the function and $\varphi_{t}=\pi / 2$ is the phase of the function.

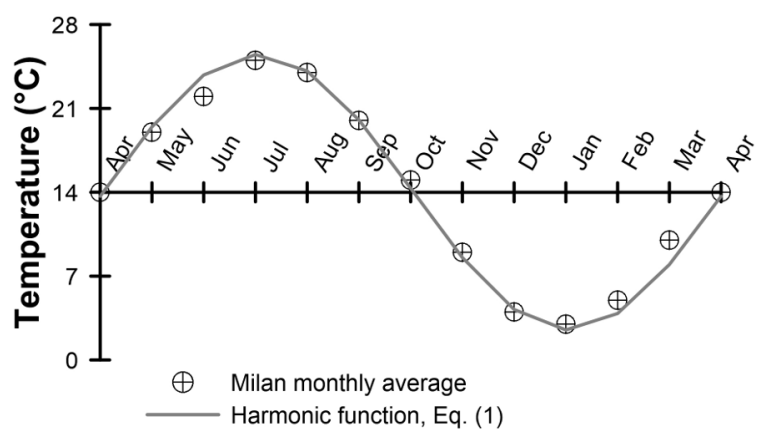

Fig. 2. Milan average monthly temperatures compared with Equation (1). Temperature data from https://www.timeanddate.com/weather/italy/milan/climate 
Table 3. Thermal boundary conditions used in study.

\begin{tabular}{|c|c|c|c|c|c|}
\hline Boundary & Greenfield & Comb. 1 & Comb. 2 & Comb. 3 & Comb. 4 \\
\hline Centreline & Adiabatic & Adiabatic & Adiabatic & Adiabatic & Adiabatic \\
\hline Top & Harmonic & $\mathrm{T}=\mathrm{T}_{0}$ & $\mathrm{~T}=\mathrm{T}_{0}$ & Adiabatic & Adiabatic \\
\hline Side & Adiabatic & $\mathrm{T}=\mathrm{T}_{0}$ & Adiabatic & $\mathrm{T}=\mathrm{T}_{0}$ & Adiabatic \\
\hline Bottom & $\mathrm{T}=\mathrm{T}_{\text {avg }}$ & $\mathrm{T}=\mathrm{T}_{0}$ & Adiabatic & $\mathrm{T}=\mathrm{T}_{0}$ & Adiabatic \\
\hline Pile & Harmonic & Harmonic & Harmonic & Harmonic & Harmonic \\
\hline
\end{tabular}

\section{Temperature $\left({ }^{\circ} \mathrm{C}\right)$}

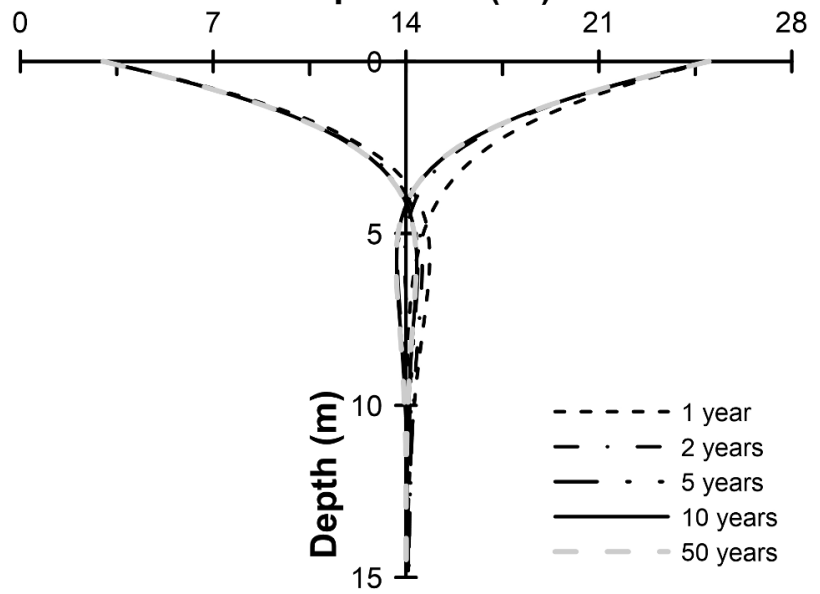

Fig. 3. Greenfield temperature field (below $13 \mathrm{~m}, \mathrm{~T} \approx \mathrm{T}_{\text {avg }}$ ).

In this phase of the calculation, adiabatic conditions were assumed along the side boundaries and a constant temperature $\left(\mathrm{T}_{0}=14^{\circ} \mathrm{C}\right)$ was specified on the bottom boundary.

Having established the Greenfield temperature field, a further 10 years of thermally-activated pile operation was modelled. Table 3 outlines the combinations of thermal boundary conditions that have been applied in each analysis, where Comb. 1 to Comb. 4 try to cover the range of assumptions summarised in Table 1. In all of the analyses, the starting top surface boundary condition is maintained throughout the analysis, i.e. is not changed to reflect the impact of a climate controlled building above the foundations.

After initialising the problem domain and before applying the pile thermal loading, a load of $3500 \mathrm{kN}$ was applied to the pile. This load implies a global factor of safety and a factor of safety on ultimate shaft resistance of about 2.0. The applied pile thermal loading is also identified in Table 3; in all cases an harmonic function the same as Equation (1) was used with $\mathrm{T}_{\mathrm{avg}}=14^{\circ} \mathrm{C} ; \Delta \mathrm{T}$ $=12^{\circ} \mathrm{C} ; \mathrm{P}=1$ year and $\varphi_{\mathrm{t}}=\pi / 2$.

\section{Results and Discussion}

\subsection{Axial thermal actions}

Axial thermal actions predicted by the differing analyses during the 10 year "operational" period are illustrated in Fig. 4 which shows the development of the maximum thermal axial stress at the end of each heating or cooling season throughout the 10 years simulated. In the Greenfield analysis, the thermal actions vary between $400 \mathrm{kN}$ in compression (negative) and $460 \mathrm{kN}$ in tension, at the end of each summer and winter respectively.

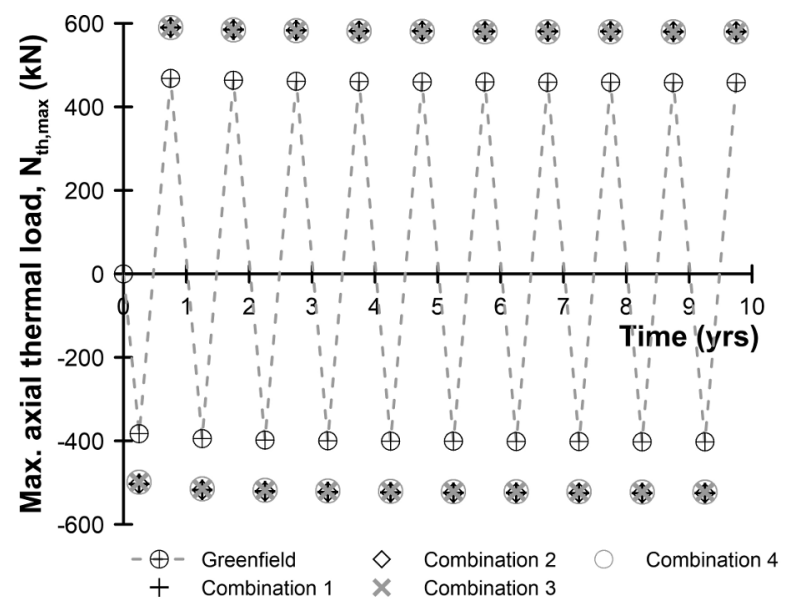

Fig. 4. Pile thermal axial load (tension positive).

The various combinations of boundary condition yield very similar thermal actions which are somewhat larger than those for the Greenfield case; $525 \mathrm{kN}$ compression and 580 tension. There is a slight tendency for the maximum tensile thermal actions to reduce and the maximum compression actions to increase over the 10 years.

The large differences in axial load response apparent in steady-state analyses [1,9], due to differing surface boundary conditions, are not seen here. This is due to the 
limited alterations in the temperature field caused by the cyclic pile thermal load, see Section 3.3.

A large proportion of the difference between the Greenfield and other combinations (about $120 \mathrm{kN}$ ) is generated at the pile head, Fig. 5. This is largely an effect of the temperature field; in the Greenfield analysis the temperature on this boundary is changing in the same sense as the pile, i.e. the ground around the pile head is cooling at the same time as the pile is cooling, and there is a reduction in the restraint offered at the pile head compared to the other cases.

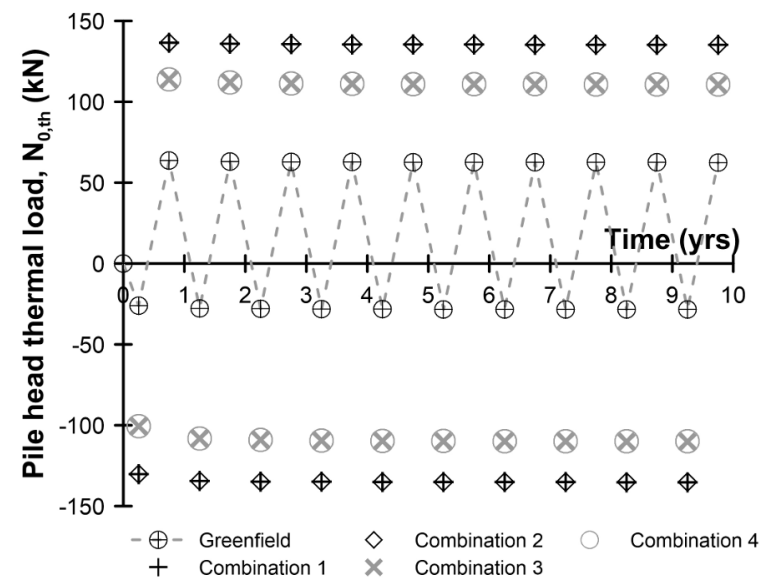

Fig. 5. Thermal reaction mobilised against pile cap.

In Comb. 1 and 2, a constant temperature surface is applied which results in a slightly larger pile head reaction than for Comb. 3 and 4 where the surface is considered as adiabatic.

The asymmetry apparent in the reactions from the Greenfield analysis are an effect of the pile cap, i.e. during cooling the pile shrinks and the pile cap bears onto the ground while during heating this reaction is not available, as the pile expands.

\subsection{Pile head thermal displacement}

Fig. 6 presents the pile head thermal displacements for the Greenfield analysis and each of the four combinations of thermal boundary condition described in Table 3. In all cases, the pile head thermal displacements are very similar throughout the 10 years of thermallyactivated pile operation analysed.

There is a very slight tendency for the maximum pile head thermal displacements due to heating (positive) to reduce, and during cooling to increase, over the 10 years. These changes are compatible with the changes in thermal axial load noted earlier.

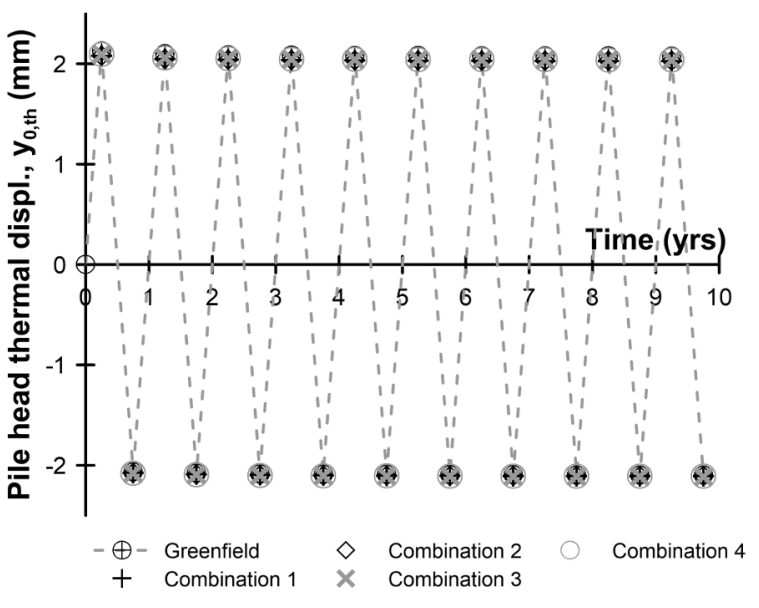

Fig. 6. Pile head thermal movement.

\subsection{Temperature field}

Fig. 7 illustrates the differences in the temperature field around the pile at mid-depth. The transient analyses (Greenfield, Comb. 1 to 4) all yield more-or-less the same radial variation in temperature, so only the results for the Greenfield analysis for the $1^{\text {st }}$ and $10^{\text {th }}$ years are shown. Steady state thermal analyses were also run for each case, to illustrate how the temperature field would change with longer term heating/cooling.

It is clear that the transient analysis with a more realistic annual cycle of heating and cooling has a much lesser impact on the soil mass. In this case, beyond about $4 \mathrm{~m}$ from the pile, ground temperatures are not significantly altered by the pile thermal loading, even after 10 years operation. It should be borne in mind that in this case a balanced thermal loading was applied, so the resultant heating/cooling should be zero.

This leads to greater pile restraint, higher thermal stress and reduced thermal movement compared to steady state conditions.

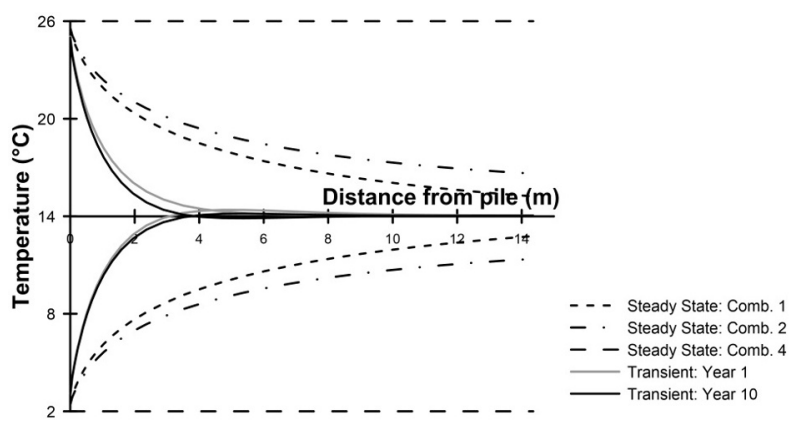

Fig. 7. Temperature field around pile at mid-depth. Note: SS - steady state thermal analysis.

\section{Conclusions}

The objective of the study presented in this paper was to establish what impact the choice of thermal boundary conditions might have on the predicted response of thermally-activated piles. The analyses did not consider the moisture condition of the soil; however, while this 
would alter the quantitative results (due to e.g. lower thermal conductivity and possibly higher pile restraint from the ground in partially saturated conditions), the trends in behaviour are likely to be similar.

An isolated, floating pile was considered. The pile was loaded mechanically to a service load which implied a global factor of safety of two which is approximately the same margin on the ultimate shaft resistance. A harmonic thermal load varying by $\pm 12^{\circ} \mathrm{C}$ across the year was applied to the pile.

The results in this case, suggest that the largest effect implied by the choice of thermal boundary condition, is in terms of the axial thermal actions and that the effect on displacements is negligible. The choice of the top surface temperature condition is the most important.

The soil coefficient of thermal expansion was assumed to be twice that for the pile. Whereas in the steady state analysis of [1] and [9], this lead to substantial changes in axial stress (Fig. 1) and pile head movement, in these balanced transient thermal analyses the same effect was not seen. This is a consequence of the volume of thermally-activated soil being substantially reduced in the latter case, Fig. 7.

In this case, where the factor of safety on shaft resistance was large, no significant cyclic thermal ratcheting was predicted, unlike e.g. [18] where the shaft resistance was largely mobilised at working load.

Further work is planned to examine the effect of thermal boundary condition assumptions for end-bearing piles and piles in cohesion-less materials, especially where the margin of safety on the shaft resistance is reduced, and the effect of the overlying structure.

\section{Acknowledgements}

This work was undertaken as part of the project DEEPCOOL (PTDC/ECI-EGC/29083/2017) financed by the Fundação para c Ciência e a Tecnologia (FCT), Portugal. The work of the third author was partly funded through a Special Scientific Mission granted by COST Action TU1405 - European network for shallow geothermal energy applications in buildings and infrastructures.

\section{References}

1. Bodas Freitas, T.M., Cruz Silva, F., Bourne-Webb, P.J. (2013). The response of energy foundations under thermo-mechanical loading, Proc. of the 18th Intl. Conf. on Soil Mech. and Geot. Eng'g, Paris, 3347-3350

2. Di Donna, A., Dupray, F., Laloui, L. (2013). Effect of thermo-plasticity of soils on the design of energy piles, EGC2013, Proc. European Geothermal Congress, Pisa, Italy, Paper SG4-03, 10 pages

3. Dupray, F., Laloui, L., Kazangba, A. (2014). Numerical analysis of seasonal heat storage in an energy pile foundation, Computers and Geotechnics, 55(January): 67-77

4. Saggu, R. and Chakraborty, T. (2014). Thermal analysis of energy piles in sand, Geomechanics and Geoengineering, 10(1): 10-29
5. Salciarini, D., Ronchi, F., Cattoni, E., Tamagnini, C. (2015). Thermomechanical effects induced by energy piles operation in a small piled raft, Intl. J. of Geomechanics, 15(2): 1-14

6. Wang, W., Regueiro, R.A., McCartney, J.S. (2015). Coupled Axisymmetric Thermo-Poro-Mechanical Finite Element Analysis of Energy Foundation Centrifuge Experiments in Partially Saturated Silt. Geotech. Geol. Eng., 2015, 33(2):373-388

7. Di Donna, A. and Laloui, L. (2015). Numerical analysis of the geotechnical behaviour of energy piles, Int. J. Numer. Anal. Meth. Geomech. 2015; 39: 861-888

8. Rotta Loria, A.F., Gunawan, A., Shi, C., Laloui, L., $\mathrm{Ng}, \mathrm{C} . W . W .(2015)$. Numerical modelling of energy piles in saturated sand subjected to thermomechanical loads, Geomechanics for Energy and the Environment 1(April): 1-15

9. Bourne-Webb, P.J., Bodas Freitas, T.M., Assução, R.M. (2016). Soil-pile thermal interactions in energy foundations, Geotechnique, 66(2): 167-171

10. Khosravi, A., Moradshahi, A., McCartney, J.S., Kabiri, M. (2016). Numerical analysis of energy piles under different boundary conditions and thermal loading cycles, Proc. 3rd European Conference on Unsaturated Soils, "E-UNSAT 2016", 6 pages, https://doi.org/10.1051/e3sconf/20160905005

11. Tsetoulidis, C., Naskos, A., Georgiadis, K. (2016). Numerical investigation of the mechanical behaviour of single energy piles and energy pile groups, Energy Geotechnics (Wuttke, F., Bauer, S., Sánchez, M. eds), CRC Press, pp. 569-575

12. Rotta Loria, A.F. \& Laloui, L. (2016). The interaction factor method for energy pile groups, Computers and Geotechnics 80(December): 121137

13. Gawecka, K.A., Taborda, D.M.G., Potts, D.M., Cui, W., Zdravkovic, L., Haji Kasri, M.S. (2017). Numerical modelling of thermo-active piles in London Clay, Proc. of the Institution of Civil Engineers, Geotechnical Engineering 170(GE3): 201-219

14. Salciarini, D., Ronchi, F., Tamagnini, C. (2017). Thermo-hydro-mechanical response of a large piled raft equipped with energy piles: a parametric study, Acta Geotechnica, 12(4): 703-728

15. Alberdi-Pagola, M., Madsen, S., Lund Jensen, R., Erbs Poulsen, S. (2017). Numerical investigation on the thermo-mechanical behavior of a quadratic cross section pile heat exchanger, IGSHPA Technical/Research Conference and Expo, Denver, 134-143 https://igshpa.org/2017/conferenceproceedings/index.html\#134, accessed 15 January 2018

16. Vieira, A., Maranha, J.R. (2017) Thermoplastic analysis of a thermoactive pile in a normally consolidated clay, Int. J. Geomech., 17(1): 


\section{0 doi: 10.1061/(ASCE)GM.1943-} 5622.0000666

17. Georgiadis K., Skordas D., Kamas I., Comodromos E. (2018) Heating and cooling induced stresses and displacements in heat exchanger piles in sand, Renewable Energy, doi: 10.1016/j.renene.2018.11.078.

18. Rammal D., Mroueh H., Burlon S. (2018) Impact of thermal solicitations on the design of energy piles, Renewable and Sustainable Energy Reviews, 92(Sept.):111-120, doi: 10.1016/j.rser.2018.04.049.

19. Sani A.K., Singh R.M. (2018) Response of unsaturated soils to heating of geothermal energy pile, Renewable Energy, doi: 10.1016/j.renene.2018.11.032.

20. Adinolfi M, Maiorano RMS, Mauro A, Massarotti $\mathrm{N}$, Aversa S (2018) On the influence of thermal cycles on the yearly performance of an energy pile, Geomechanics for Energy and the Environment, 16(Dec.): 32-44, doi: 10.1016/j.gete.2018.03.004.

21. Bourne-Webb PJ, Bodas Freitas TM, Freitas Assunção RM (2019) A review of pile-soil interactions in isolated, thermally-activated piles, Computers and Geotechnics 108(April): 61-74, doi: 10.1016/j.compgeo.2018.12.008

22. Bourne-Webb P.J., Amatya, B., Soga K., Amis, A., Davidson, C., Payne P. (2009). Energy pile test at Lambeth College, London: geotechnical and thermo-dynamic aspects of pile response to heat cycles, Géotechnique 59(3): 237-248

23. Zito, M. (2019) Transient analysis of building-pilesoil interactions in thermally-activated foundations, Masters Thesis, Politecnico di Milano 